\title{
Glucose and other insulin secretagogues induce, rather than inhibit, expression of $I d-1$ and $I d-3$ in pancreatic islet beta cells
}

\author{
B.M. Wice, E. Bernal-Mizrachi, M. A. Permutt \\ Department of Internal Medicine, Division of Metabolism, Washington University School of Medicine, Saint Louis, Missouri, \\ USA
}

\begin{abstract}
Aims/hypothesis. Basic helix loop helix transcription factors regulate insulin gene transcription. Therefore, molecules that regulate their function should affect insulin production and secretion. As Id proteins inhibit basic helix loop helix function, it is important to determine whether they are expressed in beta cells and if insulin secretagogues regulate their expression. Methods. Human islets or insulinoma cells were cultured in different glucose concentrations or treated with secretagogues. Insulin secretion was measured using RIA. The Id mRNA and protein concentrations were measured using northern blots, RT-PCR, and western blots. Transfections of promoter-reporter constructs were used to estimate $I d-1$ gene transcription.

Results. The Id-1 mRNA concentrations were twofold higher in islets cultured overnight in $10 \mathrm{mmol} / \mathrm{l}$ than in $2.5 \mathrm{mmol} / \mathrm{l}$ glucose. Addition of high glucose to islets previously cultured in low glucose, increased Id-1 mRNA concentrations within $30 \mathrm{~min}$. Analyses
\end{abstract}

using insulinoma cells revealed that Id-1 and Id-3 mRNA concentrations peaked $30 \mathrm{~min}$ after glucose was added, returned to near basal concentrations by $2 \mathrm{~h}$ and then progressively increased for $24 \mathrm{~h}$. The Id-1 protein concentrations changed in a similar pattern. Insulin secretagogues that act through different signaling pathways also induced Id expression. The Id response required glucose metabolism, calcium, and RNA synthesis but not protein synthesis. Glucose-responsive elements are confined to the 5'-region of the $I d-1$ gene.

Conclusion/interpretation. The concomitant induction of $I d-1$ and $I d-3$ expression, insulin gene transcription, and insulin secretion suggests that physiological concentrations of Ids do not inhibit insulin gene transcription and Ids could play unexpected and novel roles in promoting beta-cell function. [Diabetologia (2001) 44: 453-463]

Keywords Id-1, Id-2, Id-3, helix loop helix, basic helix loop helix, insulin secretion, insulin gene transcription, beta cell.
After glucose-induced insulin secretion, pancreatic islet beta cells must replenish insulin stores so that an ample supply is ready for secretion following the

Received: 17 July 2000 and in revised from: 10 January 2001

Corresponding author: B.M. Wice, $\mathrm{PhD}$, Washington University School of Medicine, Department of Internal Medicine, Division of Metabolism/Campus Box 8127, 660 South Euclid Avenue, Saint Louis Missouri, 63110, USA

Abbreviations: HLH, Helix loop helix; bHLH, basic helix loop; TAg, SV40 T antigen; HDF, human diploid fibroblasts; BrdU, 5'-bromo-2'-deoxyuridine; $\mathrm{Cy} 3$, indocarbocyanine 3 ; $\mathrm{KCl}$, potassium chloride. next meal. Over short periods of time $(710 \mathrm{~min})$, this is accomplished by increased translation of pre-existing mRNA molecules. Regulation of insulin gene transcription is, however, essential for long-term (hours or days) maintenance of insulin stores [1, 2]. Therefore, it is important to understand the molecular mechanisms that regulate insulin gene transcription. Insulin promoter sequences are highly conserved among species with the first approximate 400 nucleotides being sufficient to confer most beta-cellspecific and glucose-regulated transcription [3, 4]. Beta-cell-specific expression results from a unique combination of tissue-restricted and ubiquitously ex- 
pressed transcription factors. In the rat insulin I promoter, two E-box elements "GCCATCTGC" (E1 and E2) that bind basic helix loop helix (bHLH) transcription factors are crucial for promoter activity. Removal of either E1 or E2 results in a tenfold reduction in promoter activity and removal of both elements essentially abolishes activity [5]. Juxtaposed to E1 and E2 are A-box elements which have a core sequence of "TAAT" that is recognized by homeodomain containing transcription factors. Some, but not all, factors that bind the A-boxes can interact with proteins bound to the E-box to synergistically activate transcription from the insulin promoter. For example, the E1 element alone, when linked to a minimal insulin promoter, is sufficient to confer a threefold increase in glucose-regulated promoter activity, whereas inclusion of the E1, A2 and $\mathrm{C} 1$ elements results in a fivefold increase in the glucose response [6]. These observations indicate that bHLH proteins bound to their cognate E-boxes play fundamental roles in regulating basal and glucose responsive transcription of the insulin gene in co-operation with juxtaposed homeodomain proteins bound to their cognate Abox elements.

The bHLH proteins function as dimers and are important in regulating cell determination and differentiation in many developmental systems [7-10]. The helix loop helix (HLH) domains promote dimerization while the basic domains mediate DNA binding. Homodimers of class B tissue-restricted bHLH proteins activate transcription of "master" regulatory genes that commit cells to a particular lineage but typically do not activate transcription of differentiation-associated genes. The class B bHLH proteins can also form heterodimers with ubiquitously expressed class A bHLH proteins (also known as Eproteins; e.g. the $E 2 A$ gene products E12 and E47). In most cases, these heterodimers activate transcription of differentiation-associated genes. In islet betacells, homodimers composed of the class B bHLH, BETA2 (also known as NeuroD), do not activate insulin gene transcription whereas heterodimers composed of an E protein plus BETA2 greatly enhance insulin promoter activity [11]. BETA2 is critical for beta-cell development and function in vivo because islets in BETA2 $2^{--}$mice exhibit abnormal morphology and reduced beta-cell number; these mice die of severe diabetes shortly after birth [12]. Mutations in the human BETA2 gene that result in decreased DNA binding or trans-activation are associated with the development of Type II (non-insulin-dependent) diabetes mellitus [13]. Conversely, E2 $\mathrm{A}^{-/-}$mice show normal blood glucose concentrations and pancreatic insulin content suggesting that BETA 2 can also function by heterodimerizing with E-proteins encoded by the E2-2 and E2-5 genes [14, 15]. These results illustrate the importance of BETA2 for beta-cell function and suggest that factors modulating BETA2:E-pro- tein dimerization are very likely to regulate insulin gene transcription and beta-cell physiology.

The four Ids (Id-1, Id-2, Id-3, and Id-4) are naturally occurring, dominant-negative HLH proteins that lack the basic domain required for DNA binding [7, $8,16]$. Each Id is encoded by a different gene and forms high affinity heterodimers with all E-proteins [17]. These heterodimers cannot bind DNA and therefore, inhibit bHLH-dependent transcription by sequestering E-proteins. Because of this, ectopic expression of Ids has been used to show that bHLH proteins regulate differentiation in numerous in vitro and several in vivo systems [18-26]. One such study showed that forced expression of Id-1 in insulinoma cells inhibited insulin promoter-reporter activity [22]. Although this experiment succeeded in showing a potential role for bHLH proteins in insulin gene transcription, it did not address whether Id genes are expressed in islet beta-cells in vivo or if glucose regulates expression of $I d$ genes.

In addition to their ability to sequester E-proteins, individual Id proteins can interact in distinct ways with non-bHLH proteins to regulate cellular functions. Ids can bind to transcription factors containing an ETS-domain [27]. This interaction is capable of inhibiting transcription of genes containing serum response elements. There is also considerable evidence that Ids can regulate cell proliferation [16, 28-31] and apoptosis [32-35]. The Id-1 protein can interact with S5A, a protein thought to shuttle multi-ubiquitinated proteins to the $26 \mathrm{~S}$ proteasome for degradation [36]. Many proteins degraded by the ubiquitin system include short-lived regulatory proteins such as cell cycle regulators, transcription factors, and tumor suppressors [37, 38]. Therefore, alteration of S5A availability could have profound effects on beta-cell physiology. These results emphasize that Ids are multifunctional proteins and might not be general inhibitors of cell differentiation.

The rate of insulin gene transcription increases in response to increased blood glucose concentration. The bHLH transcription factors are essential for glucose-regulated, insulin gene expression and Id proteins are thought to inhibit bHLH-dependent transcription by sequestering E proteins. It is therefore, important to define the pattern of Id- 1 mRNA expression in pancreatic islet beta cells and to determine whether glucose and other insulin secretagogues regulate $I d$ expression.

\section{Materials and Methods}

Cell lines and culture conditions. Cells were cultured at $37^{\circ} \mathrm{C}$ in an atmosphere of $5 \% \mathrm{CO}_{2}$ and $95 \%$ air with $100 \%$ humidity. The $\beta$ TC6-F7 [39] (passage 22-35) and $\beta$ TC-tet [40] (passage 36-50) cells were generously provided by S. Efrat (Tel Aviv University, Israel) and cultured in DMEM containing $2.5 \%$ 
FCS and $15 \%$ horse serum. To inhibit T antigen (TAg) production, $\beta$ TC-tet cells were cultured for 7 days in complete medium supplemented with $1 \mu \mathrm{mol} / 1$ tetracycline. The MIN6 cells [41] (passage 25-40) were obtained from Y. Oka (Institute for Medical Genetics, Kumamoto, Japan) and cultured in DMEM containing $15 \%$ FCS. The NIH 3 T3 mouse fibroblasts were obtained from the ATCC and cultured in DMEM containing $10 \%$ bovine calf serum. The AG 1523A normal human diploid fibroblasts (HDFs) were obtained from the Human Genetic Cell Repository and cultured in MEM (Earle's salts) containing $20 \%$ FCS, $2 \mathrm{X}$ vitamins, and $2 \mathrm{X}$ essential and nonessential amino acids. Growth arrest of human and mouse fibroblasts was accomplished by culturing cells for 48 or $24 \mathrm{~h}$, respectively, in complete media containing $1 \%$ serum. The NIH $3 T 3$ cells detached from the plates if cultured for $48 \mathrm{~h}$ in low serum. The $\mathrm{BC} 3 \mathrm{H} 1$ muscle-like cells [42], $\mathrm{CaCo}-2$ enterocytelike cells [43-48] and HepG2 hepatocyte-like cells [49-51] are glucose responsive. The $\mathrm{BC} 3 \mathrm{H} 1$ and $\mathrm{CaCo}-2$ cells were cultured as described previously [52, 53]. Briefly, BC3H1 cells were induced to differentiate by culturing in medium containing $1 \%$ FCS for $72 \mathrm{~h}$ [52]. Differentiation of Caco- 2 cells was accomplished by maintaining cells in a confluent state for 10 days [53]. The HepG2 cells were cultured in DMEM containing $10 \%$ FCS.

Human islets. Primary human islets were obtained from the Diabetes Research and Training Center and Juvenile Diabetes Foundation Islet Isolation Core Facility at our institution and were isolated as described [54]. The age, height (m), weight $(\mathrm{kg})$, body mass index (weight divided by [height] ${ }^{2}$ ) and length of time pancreas was in cold ischemia for organ donors 1, 2, and 3 are: 61 years old, $1.7 \mathrm{~m}, 86 \mathrm{~kg}, 29.8$ and $8 \mathrm{~h} ; 56$ years old, $1.9 \mathrm{~m}, 79.3 \mathrm{~kg}, 22$ and $7 \mathrm{~h}$; and 44 years old, $1.8 \mathrm{~m}, 105 \mathrm{~kg}, 32$ and $10 \mathrm{~h}$, respectively. All islets were isolated from men and preparations contained less than $10 \%$ exocrine pancreas. Islets were cultured in non-tissue culture treated plasticware in RPMI medium containing $10 \%$ FCS and the indicated concentration of glucose. Each sample represents a pool of about 1000 islets.

Isolation of RNA. Total cellular RNA was isolated from cultured cells, islets, and exocrine pancreas using guanidium thiocyanate homogenization and organic extraction as described [55]. Total cellular RNA was isolated from human jejunum, liver, lung, placenta and kidney samples using guanidium thiocyanate homogenization and cesium chloride centrifugation as described [55].

Northern blot analysis. Total cellular RNA (20 $\mu \mathrm{g})$ containing ethidium bromide was fractionated on agarose gels containing formaldehyde. Gels were examined under ultraviolet light to confirm that the RNA was intact and that equal amounts of RNA were loaded in each lane. The RNA was then transferred to nylon membranes and hybridized overnight at $56^{\circ} \mathrm{C}$ in Church's solution as described [55] with the indicated probe. Radioactive cDNA probes were labelled using $\left[\alpha-\mathrm{P}^{32}\right]$-dCTP, random primers and Klenow fragment. Id-1 cDNA was excised as a Bam HI fragment from $\mathrm{pLF} / \mathrm{Id}-1$ and encodes nucleotides 4-558 of the mouse Id-1 mRNA [56]. Mouse Id-2 (nucleotides 442-1051) and Id-3 (nucleotides 353-838) cDNAs were generated by RT-PCR and sub-cloned into the pCR 2 vector (Invitrogen, Carlsbad, Calif., USA). Inserts were excised using Eag I. A Pst I fragment of the rat $\beta$-actin cDNA was used to hybridize to actin gene products. After hybridization, blots were washed 3 times each in $0.1 \%$ SSC containing $1 \%$ SDS at room temperature and then at $55^{\circ} \mathrm{C}$. Radioactivity was visualized by fluorography and quantified using a Molecular Dynamics
Phosphorimager and ImageQuant software source. Before reprobing, blots were stripped by boiling in $0.1 \%$ SSC plus $0.1 \%$ SDS. Re-exposure of stripped blots confirmed that the previous radioactive probe was removed from the membranes.

$R T-P C R$ assays. One $\mu \mathrm{g}$ of total cellular RNA and $3 \mu \mathrm{g}$ random hexameric primers (Roche Molecular Biochemicals, Indianapolis, Ind., USA) were placed in a siliconized tube in a $10 \mu \mathrm{l} \mathrm{fi-}$ nal volume. Samples were incubated at $70^{\circ} \mathrm{C}$ for $5 \mathrm{~min}$ and then cooled slowly to room temperature. A $2 \mathrm{x}$-reaction mixture containing AMV reverse transcriptase (Promega, Madison, Wis., USA) was prepared according to manufacturer's protocol and then added to the RNA and primers. Samples were incubated for $1 \mathrm{~h}$ at $42^{\circ} \mathrm{C}$ to convert RNA into single stranded cDNA. Parallel reactions were done without reverse transcriptase to confirm that products generated in the subsequent PCR reactions represent RNA and not contaminating DNA. A $1 \mu \mathrm{l}$ aliquot of each reverse transcriptase reaction was transferred to separate tubes and then subjected to PCR amplification in a $30 \mu \mathrm{l}$ final volume using primers for a control RNA ( $\beta$-actin or GAPDH) or the RNA of interest. The PCR reactions included $0.05 \mu \mathrm{Ci}\left[\alpha-\mathrm{P}^{32}\right]$-dCTP in order to minimize the number of amplification cycles required to detect the appropriate cDNA. Radioactive cDNAs were fractionated through $5 \%$ acrylamide gels in $1 \mathrm{xTBE}$ after which the gels were dried and subjected to autoradiography and phosphorimager analysis. Radioactivity in the cDNA of interest was normalized to that in the control cDNA to correct for different efficiencies of each reverse transcriptase reaction. Primers used to generate cDNAs representing nucleotides 728-1076 of mouse $\beta$-actin [57], nucleotides $84-560$ of mouse Id-1 [57], and a 267 bp fragment of GAPDH [58]. Upstream and downstream primers for human Id-1 mRNA are (5')-CGT $C A T$ $C G A C T A$ CAT CAG GG-(3') and (5')-CAC AGA GCA $C G T A A T$ TCC $T C-\left(3^{\prime}\right)$, respectively. Products representing human Id-1 mRNA (nucleotides 323-566) and genomic DNA are $243 \mathrm{bp}$ and $500 \mathrm{bp}$, respectively. The GAPDH and human Id- 1 were amplified for 25 cycles $\left(7\right.$ cycles at $94^{\circ} \mathrm{C}$ for $30 \mathrm{~s}$, $60^{\circ} \mathrm{C}$ for $30 \mathrm{~s}, 72^{\circ} \mathrm{C}$ for $2 \mathrm{~min}$ followed by 18 cycles with a $55^{\circ} \mathrm{C}$ annealing temperature). Mouse $\beta$-actin and Id- 1 cDNAs were amplified for 20 and 25 cycles, respectively at $94^{\circ} \mathrm{C}$ for $30 \mathrm{~s}, 55^{\circ} \mathrm{C}$ for $1 \mathrm{~min}$, and $72^{\circ} \mathrm{C}$ for $1.5 \mathrm{~min}$. All amplifications were carried out using a GeneAmp PCR System 9700 (PE Applied Biosystems, Foster City, Calif., USA). Validity of the RTPCR assays was established by comparing previously published results $[16,57,59]$ or northern blot data with results obtained using RT-PCR.

Western blot analysis. Cells were cultured as indicated, lysed, subjected to SDS-PAGE, and transferred to nitrocellulose membranes as described [60]. Equal loading of samples was confirmed by staining membranes with Ponceau S. Membranes were then blocked overnight at $4{ }^{\circ} \mathrm{C}$ using $0.2 \%$ Tween 20 and $5 \%(\mathrm{~W}: \mathrm{V})$ non-fat dry milk in PBS. After blocking, membranes were incubated with rabbit anti-peptide antibodies specific for Id-1 (antibody C-20 directed against residues 129-148 of human Id-1; 200 ng/ml; Santa Cruz Biotechnology, Inc, Santa Cruz, Calif., USA). Bound antibodies were detected using the ECL western blotting detection system (Amersham Life Science; Arlington Heights, Ill., USA) according to the manufacturer's protocol. Control lysates containing high and low concentrations of Id-1 were prepared from proliferating and quiescent NIH 3 T3 cells, respectively and electrophoresed adjacent to the samples from $\beta$ TC6-F7 cells.

Indirect immunofluorescence. The $\beta$ TC-tet cells were plated onto sterile glass coverslips in 12-well dishes and cultured 
with or without $1 \mu \mathrm{mol} / \mathrm{l}$ tetracycline. Seven days later, media were brought to $20 \mu \mathrm{mole} / \mathrm{l}$ of 5'-bromo-2'-deoxyuridine (BrdU) plus $2 \mu \mathrm{mol} / 1$ of 5'-fluoro-2'- deoxyuridine from a $100 \mathrm{X}$ stock in water. Cells were incubated for an additional $2 \mathrm{~h}$ at $37^{\circ} \mathrm{C}$, washed twice with $\operatorname{PBS}\left(0^{\circ} \mathrm{C}\right)$ and then fixed for $15 \mathrm{~min}$ in Bouin's solution $\left(0^{\circ} \mathrm{C}\right)$. Fixed cells were washed with PBS and brought (stepwise) to $70 \%$ ethanol. For antibody staining, cells were re-hydrated and then washed with PBS. Incorporated into DNA the BrdU was rendered accessible to antibodies by treatment with $1 \mathrm{~N} \mathrm{HCl}$ for $10 \mathrm{~min}$ at room temperature before the PBS washes. To block non-specific binding, cells were incubated for more than $30 \mathrm{~min}$ at room temperature in $0.2 \%$ Tween 20 and $5 \%$ normal donkey serum in PBS. Primary antibodies were diluted in PBS containing $0.2 \%$ Tween 20 and left on the cells overnight at $4{ }^{\circ} \mathrm{C}$. Rabbit anti-TAg (kindly provided by D. Hanahan, University of Calif., San Francisco, Calif., USA) and goat anti-BrdU (kindly provided by S. Cohn, University of Virginia, Va., USA) were used at a 1:1000 and 1:2000 dilutions, respectively. Antibodyantigen complexes were visualized with indocarbocyanine (Cy3)-conjugated donkey anti-rabbit IgG or anti-goat $\mathrm{IgG}$ (1:1000 dilutions; Jackson ImmunoResearch; West Grove, Pa., USA). Stained cells were viewed and photographed with a Zeiss Axiophot microscope.

Insulin secretion. The MIN6 and $\beta$ TC-tet cells were plated at $1.25 \cdot 10^{5}$ cells per well in 12 -well plates. Insulin secretion was measured as described [61] 4 to 5 days later unless cells were treated with tetracycline. In this case, $1 \mu \mathrm{mol} / 1$ tetracycline was added to cells 3 days after plating and insulin secretion measured on day 10. Briefly, cells were washed twice with Hank's balanced salt solution (glucose-free) and then incubated at $37^{\circ} \mathrm{C}$ in assay buffer (KRB containing Hepes, sodium bicarbonate, and BSA). One hour later, the assay buffer was replaced, the appropriate secretagogues were added, and cells were incubated for an additional $90 \mathrm{~min}$. Assay media was removed from the cells, centrifuged to remove any detached cells, and assayed for insulin by RIA (carried out by the Washington University Diabetes Research and Training Center RIA Core).

Cell transfections. The MIN6 cells were plated at $1.25 \cdot 10^{5}$ cells per well in 24-well tissue culture dishes. The next day, cells were refed with $1 \mathrm{ml}$ medium and then transfection reagent containing DNA was added to cells $[0.5 \mu \mathrm{g}$ of plasmid DNA/ $2 \mu$ LT-1 (Panvera, Madison, Wis., USA) in $50 \mu$ l Opti-MEM (Life Technologies, Gaithersburg, Md., USA)]. After 48 h cells were washed twice with complete media containing the indicated concentrations of glucose plus $2.5 \%$ FCS and then incubated for an additional $24 \mathrm{~h}$ before being harvested for luciferase activity. Luciferase was assayed using the Luciferase Reporter Assay Kit (Promega, Madison, Wis., USA) according to manufacturer's protocol. Luminescence was measured using a Monolight 3010 Luminometer (Analytical Luminescence Laboratory, Sparks, Md., USA). Regulatory sequences have been identified in regions upstream and downstream of the $I d-1$ gene [62-64]. Therefore, the ability of 5'- and 3'- Id-1 flanking sequences to regulate reporter activity in MIN6 cells was investigated. Plasmid 6.0/Luc contains $6 \mathrm{~kb}$ of sequence from the 5'-flanking region of the mouse $I d-1$ gene linked to a luciferase reporter [62]. Plasmid 6.3/Luc contains these same 5'-flanking sequences as well as $3 \mathrm{~kb}$ of 3'-flanking sequence from the $I d-1$ gene linked downstream of the luciferase reporter. This 3'-flanking region contains a pro B-lymphocyte enhancer [62]. Plasmids 6.3/Luc or 6.0/Luc were generously provided by Dr. X-H Sun (Oklahoma Medical Research Foundation, Oklahoma City, Okla., USA).
Statistical analysis. Statistical significance was calculated using the student's $t$-test (2-sample unequal variance ; 2-tailed distribution). Data for each condition was always compared to that from cells pre-incubated in $2.5 \mathrm{mmol} / \mathrm{l}$ glucose.

\section{Results}

Glucose induces rather than inhibits Id-1 mRNA expression in human islets. A RT-PCR assay was developed to measure Id-1 mRNA concentration in human islets (see Materials and Methods). The Id1 mRNA concentrations decreased about eightfold after proliferating HDFs were subjected to serum starvation for $48 \mathrm{~h}$ (Fig. 1A). Northern blot and phosphorimager analysis of the same HDF RNA samples showed a similar difference in Id- 1 mRNA concentrations (Fig.1B). In agreement with previous reports, the steady state concentrations of Id-1 mRNA vary over a wide range with high, intermediate, and low levels in lung, kidney, and liver, respectively. The steady state concentration of Id-1 mRNA in total pancreas was similar to that in quiescent HDFs. This observation is consistent with the common view that Id genes are expressed at low levels in differentiated cells. Islets, which represent about $1 \%$ of the pancreatic mass, were isolated from 2 subjects, cultured for $24 \mathrm{~h}$ in $5 \mathrm{mmol} / \mathrm{l}$ glucose and then harvested for RTPCR analysis. Id-1 (Fig. 1), Id-2, and Id-3 (not shown) mRNA concentrations were two to threefold higher than those encountered in quiescent fibroblasts. The Id-1 concentrations were similar to those encountered in adult human jejunum, placenta, and kidney but lower than concentrations in lung. Islets from a third subject were cultured for $24 \mathrm{~h}$ in media containing $2.5 \mathrm{mmol} / \mathrm{l}$ or $10 \mathrm{mmol} / \mathrm{l}$ glucose and then harvested for RNA analysis. Id-1 mRNA concentrations were two to threefold higher in islets cultured in $10 \mathrm{mmol} / \mathrm{l}$ glucose (Fig. 1C). Re-addition of high glucose to the islets pre-incubated for $24 \mathrm{~h}$ in $2.5 \mathrm{mmol} / \mathrm{l}$ glucose increased Id-1 mRNA concentrations $50 \%$ within $30 \mathrm{~min}$ (not shown). These results indicate that Id-1 concentrations increase rather than decrease under conditions in which insulin gene transcription is augmented.

Survey of secretory responses of MIN6 cells. Only about $50 \%$ of the cells in adult human islets are betacells. Therefore, we analysed insulin producing betacell lines to determine whether they could recapitulate observations obtained with human islets. In vivo, glucose-induced insulin secretion requires glucose metabolism. The resulting increase in the AT$\mathrm{P}$ :ADP ratio inhibits the $\mathrm{K}_{\mathrm{ATP}}$ channel which in turn causes cell depolarization, influx of extra-cellular calcium and insulin secretion. Addition of $25 \mathrm{mmol} / \mathrm{l}$ glucose to the MIN6 cells pre-incubated for $24 \mathrm{~h}$ in low glucose elicited a five to tenfold increase in insu- 

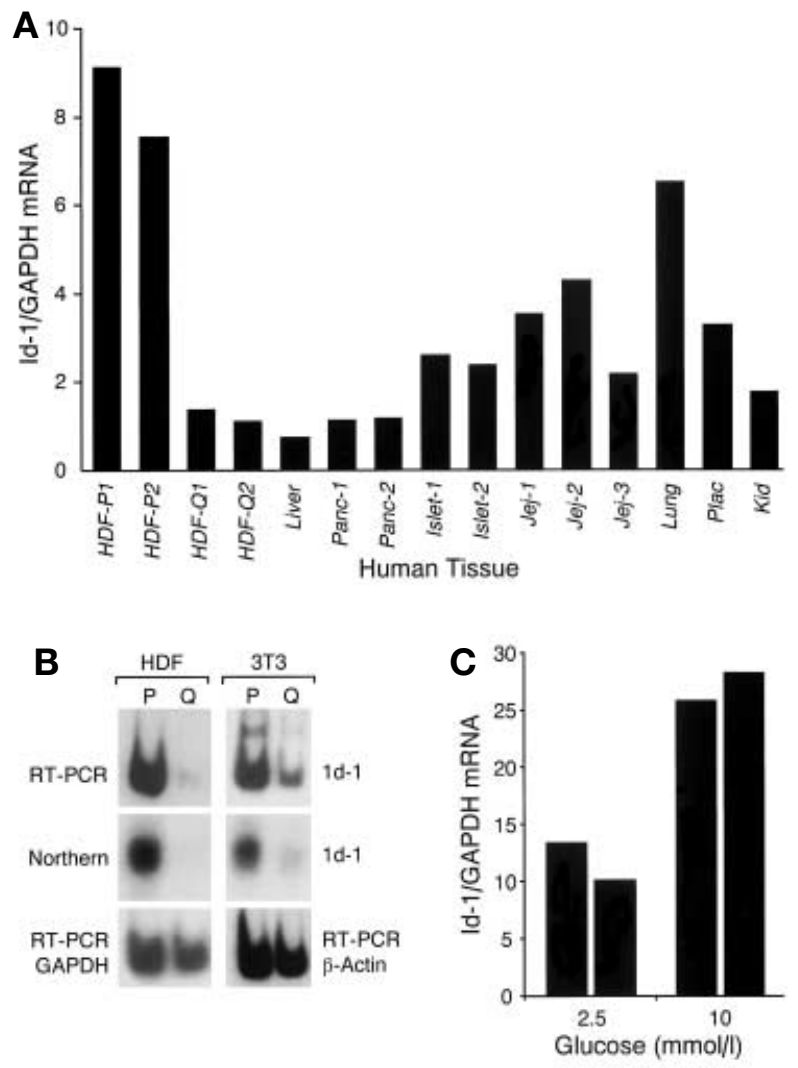

Fig.1(A-C). Glucose induces Id-1 mRNA expression in pancreatic islet beta cells. (A) RNA was isolated from the indicated human tissues and subjected to RT-PCR. The ratio of Id-1/ GAPDH mRNA reflects the relative amount of Id-1 mRNA, and not the absolute ratio of Id-1/GAPDH, in the indicated tissues. The number represents RNA samples from independent cultures of HDFs or tissue from different subjects. Islets-1 and -2 were from donors 1 and 2, respectively. (B) RNA was isolated from proliferating $(\mathrm{P})$ or quiescent $(\mathrm{Q}) \mathrm{HDFs}$ or $\mathrm{NIH}$ 3T3 (3T3) cells and subjected to RT-PCR and northern blot analyses using primers and probes specific for Id-1 or control mRNAs ( $\beta$-actin for 3 T3 cells and GAPDH for HDFs). (C) Duplicate aliquots of adult human islets from donor 3 were cultured for $24 \mathrm{~h}$ in media containing the indicated concentration of glucose and were then harvested and subjected to RTPCR analysis to measure relative Id- 1 mRNA concentrations. The different ratios for Id-1:GAPDH in islets (panels A vs C) result from different exposure times to the phosphorimager screens and not different concentrations of Id- 1 in the different subjects. HDF, human diploid fibroblasts; P, proliferating; Q, quiescent; Panc, whole pancreas; Jej, jejunum; Plac, placenta; and Kid, kidney

lin secretion (Fig. 2). The glucose analogues 2-deoxyglucose (Fig. 2) or 3-O-methylglucose (not shown) had no effect indicating that glucose metabolism was required for insulin secretion. Potassium chloride $(\mathrm{KCl})$ induces insulin secretion by direct depolarization of beta cells. Likewise, $\mathrm{KCl}$ induced insulin secretion in MIN6 cells. Arginine (through influx of positive charge) and leucine (by metabolism and generation of ATP) also increased insulin secretion by MIN6 cells. Therefore, classic beta-cell secretagogues

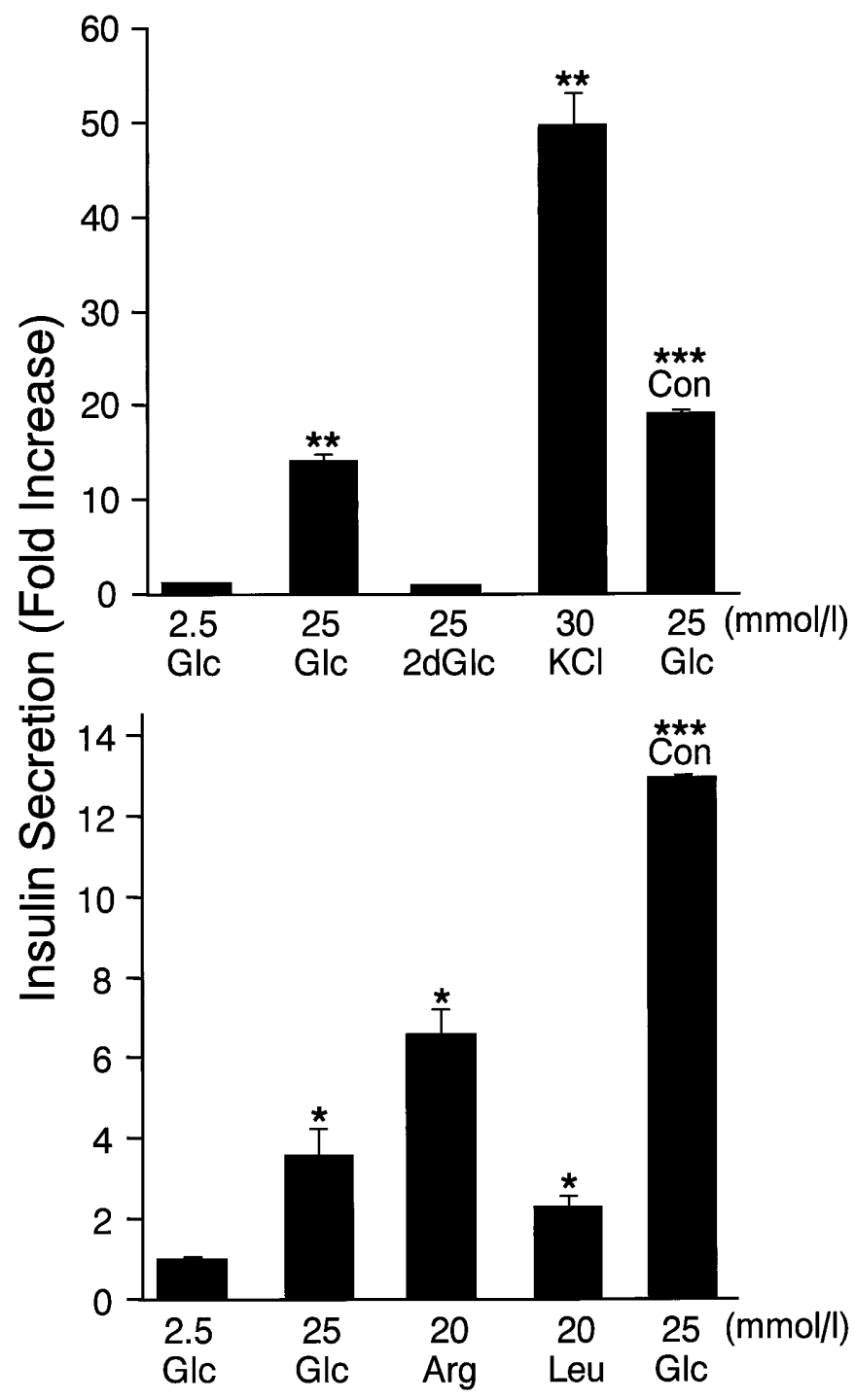

Fig. 2. Insulin secretagogues induce insulin secretion in MIN6 cells. MIN6 cells previously cultured for $24 \mathrm{~h}$ in $2.5 \mathrm{mmol} / \mathrm{l} \mathrm{glu}-$ cose were treated with the indicated secretagogue. Control cells were maintained in $25 \mathrm{mmol} / \mathrm{l}$ glucose for the entire experiment. Similar results were obtained in at least 2 experiments for each condition ( $n=3$ to 6 for each condition in each experiment). "Fold Increase" and statistical analyses are relative to secretion by cells incubated only in $2.5 \mathrm{mmol} / \mathrm{l}$ glucose. Values are $\pm \operatorname{SEM}(1,2$, and 3 asterisks represent $p$ values less than $0.05,0.01$, and 0.001 , respectively). Con, control; Glc, glucose; 2dGlc, 2-deoxyglucose; $\mathrm{KCl}$, potassium chloride; Arg, arginine; Leu, leucine

rapidly induce insulin secretion by MIN6 cells. A glucose challenge $(25 \mathrm{mmol} / \mathrm{l})$ of MIN6 cells maintained in $25 \mathrm{mmol} / \mathrm{l}$ glucose at all times compared with cells pre-incubated for $24 \mathrm{~h}$ in $2.5 \mathrm{mmol} / 1$ glucose was also conducted. Cells chronically maintained in high glucose secreted more insulin than those pre-incubated in low glucose. Therefore, MIN6 cells exhibit shortterm and long-term adaptations to high glucose. These results indicate that MIN6 cells represent a good in vitro model for glucose-responsive beta cells. 


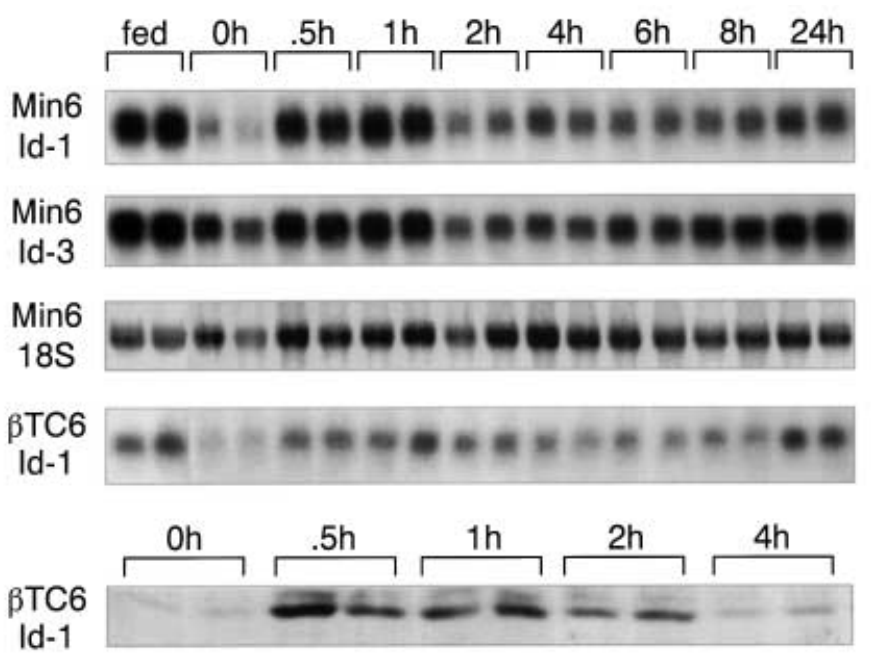

Fig. 3. Glucose induces a biphasic increase in $I d-1$ expression in insulinoma cells. Cells were harvested at the indicated time after addition of glucose and then analysed by northern blots to measure mRNA concentrations (top 4 panels) or western blots to estimate protein concentrations (lower panel). Control cells (Fed) were maintained in $25 \mathrm{mmol} / \mathrm{l}$ glucose at all times. A reverse image of the $18 \mathrm{~S}$ ribosomal RNA band is shown to confirm equal loading of the RNA gels. Each sample represents an independent dish of cells. Complete time courses of Id mRNA expression were done twice with $\beta$ TC6 cells and once with MIN6 cells whereas the western blots were done twice with MIN6 cells and once with $\beta$ TC6 cells

Glucose regulates Id-1 expression in insulin producing cell lines. Next, it was determined whether glucose regulates Id-1 mRNA concentrations in MIN6 cells. Phosphorimager analysis of the gel indicated that the steady state concentration of Id- 1 mRNA was fivefold higher in cells chronically maintained in $25 \mathrm{mmol} / 1$ glucose (Fed) than in cells cultured for $24 \mathrm{~h}$ in $2.5 \mathrm{mmol} / \mathrm{l}$ glucose $(0 \mathrm{~h})$ (Fig. 3). Addition of $25 \mathrm{mmol} / \mathrm{l}$ glucose to the cells pre-incubated for $24 \mathrm{~h}$ in $2.5 \mathrm{mmol} / 1$ glucose resulted in a rapid and transient increase in Id-1 mRNA concenrations that peaked within $30 \mathrm{~min}$, decreased by $2 \mathrm{~h}$, and then steadily increased over the next 24 to $48 \mathrm{~h}$ until concentrations returned to those observed in cells maintained in $25 \mathrm{mmol} / \mathrm{l}$ glucose. A similar experiment using $\beta$ TC6-F7 cells, another glucose-responsive insulinoma clonal cell line, showed an essentially identical pattern of glucose-regulated Id-1 mRNA expression (Fig.3). When the blots were stripped and re-probed using a $\beta$-actin cDNA, no changes in mRNA expression were observed indicating that glucose does not effect global mRNA expression in beta cells (not shown). Western blot analysis of the $\beta$ TC6-F7 (Fig. 3, bottom panel) and MIN6 cells (not shown) showed that Id-1 protein concentrations also increased rapidly and transiently in response to high glucose (Fig.3, bottom panel). Id-1 protein returned to maximum concentrations $24 \mathrm{~h}$ after addition of high glucose (not shown).

\section{Lo Glc Hi Glc}

\section{$\mathrm{BC} 3 \mathrm{H} 1$}
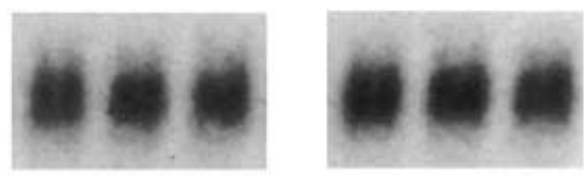

\section{HepG2}
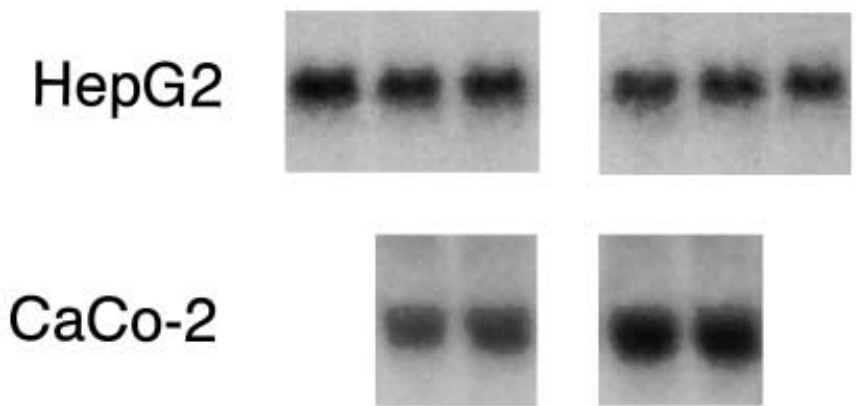

Fig.4. Glucose does not induce $I d-1$ expression in all cells. RNA was isolated from HepG2 or differentiated $\mathrm{BC} 3 \mathrm{H} 1$ and $\mathrm{CaCo}-2$ cells that were cultured in media containing $1 \mathrm{mmol} / \mathrm{l}$ glucose (Lo Glc) for $24 \mathrm{~h}$. As indicated, some cells received $25 \mathrm{mmol} / 1$ glucose (Hi Glc) for the final $30 \mathrm{~min}$. Twenty $\mu \mathrm{g}$ of RNA was subjected to northern blot analysis. Each sample represents an independent dish of cells. Similar results were obtained in a second, independent experiment $(n=3$ in each experiment)

To determine whether glucose regulates expression of other $I d s$, the northern blots were stripped and re-analysed using cDNA probes for Id- 2 and Id3 . Id-1 and Id-3 mRNA concentrations changed in parallel after adding $25 \mathrm{mmol} / \mathrm{l}$ glucose (Fig. 3 and not shown). Similar results were observed with the $\beta$ TC6-F7 cells (not shown). Conversely, glucose had much less effect on the steady-state concentrations of Id-2 mRNA in either MIN6 or $\beta$ TC6-F7 cells (not shown).

Glucose does not regulate Id $m R N A$ levels in all cells. We examined $I d$ expression in $\mathrm{BC} 3 \mathrm{H} 1, \mathrm{CaCo}-2$, and HepG2 glucose-responsive non-beta-cell lines to determine whether glucose induction of Id mRNA is a general response to rapidly changing metabolic conditions. Glucose had little effect on Id-1 (Fig.4) or Id-3 (not shown) mRNA concentrations in BC3H1 or HepG2 cells but caused a $50 \%$ increase in Id-1 concentrations after addition to $\mathrm{CaCo}-2$ cells.

Id-1 $\mathrm{mRNA}$ concentrations rapidly increase in response to insulin secretagogues. If Id-1 and Id-3 participate in a rapid glucose response in beta cells, treatment with additional insulin secretagogues might also rapidly increase expression of these mRNAs. To test this hypothesis, MIN6 cells were treated with various insulin secretagogues for $30 \mathrm{~min}$. Like glucose, $\mathrm{KCl}$ induced a rapid increase in Id-1 (Fig. 5) and Id-3 (not shown) mRNA concen- 


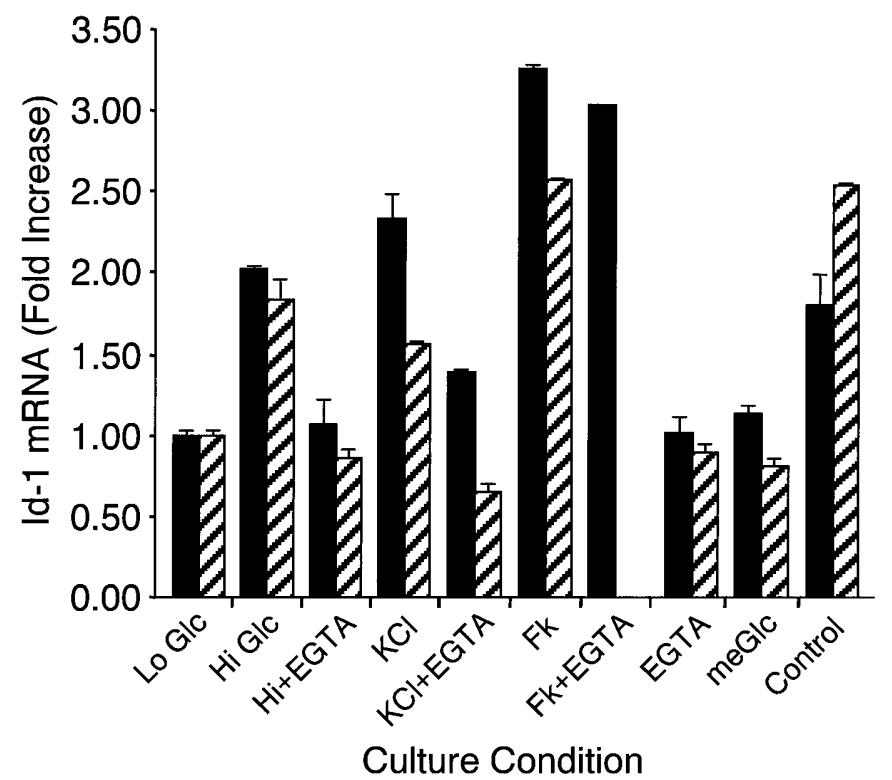

Fig. 5. Insulin secretagogues induce Id-1 mRNA in MIN6 cells. Cells were cultured as in Fig. 3. After $24 \mathrm{~h}$ in $2.5 \mathrm{mmol} / 1$ glucose (Lo Glc), some cells were treated for $30 \mathrm{~min}$ with the indicated compounds. When present, $2.5 \mathrm{mmol} / \mathrm{l}$ EGTA was added $5 \mathrm{~min}$ before addition of $25 \mathrm{mmol} / \mathrm{l} \mathrm{Glc}$ (Hi Glc), $30 \mathrm{mmol} / \mathrm{l} \mathrm{KCl}$, or $20 \mu \mathrm{mol} / 1$ forskolin $(\mathrm{Fk})$. Control cells were maintained in $25 \mathrm{mmol} / \mathrm{l}$ glucose at all times. The non-metabolizable glucose analog 3-O-methylglucose (meGlc) was added to a final concentration of $25 \mathrm{mmol} / \mathrm{l}$. "Fold Increase" is relative to Id-1 mRNA concentrations in cells cultured for $24 \mathrm{~h}$ in low glucose. Solid and hatched bars represent results from 2 independent experiments ( $n=3$ for each condition in each experiment). Values are \pm SEM

trations. This induction required an influx of extracellular calcium since EGTA prevented the response (Fig.5). Forskolin, an activator of adenyl cyclase, also induced $I d$ expression in MIN6 cells. The EGTA did not prevent this increase indicating that cAMP works by mobilizing calcium from intra-cellular stores. Acetylcholine, which stimulates insulin release by binding to muscarinic receptors on beta cells and activation of the phospholipase $\mathrm{C}$ pathway, also induced Id-1 mRNA expression (not shown). Arginine and leucine also induced a rapid increase in Id1 mRNA concentrations in MIN6 cells (not shown). Therefore, treatment of MIN6 cells with a host of insulin secretagogues which act through many different signalling pathways (e.g. depolarization, cAMP, or phospholipase $C$ ) results in rapid increases in Id-1 and Id-3 mRNA concentrations.

The rapid increase in Id mRNA concentrations suggested that Id expression could be associated with an "early growth response" in beta cells. Typically, expression of early growth response genes is induced by serum or growth factors, or both, does not require new protein synthesis but is dependent upon RNA synthesis. Treatment with either cycloheximide or glucose alone resulted in a 1.5 -fold to 2.5 -fold in-

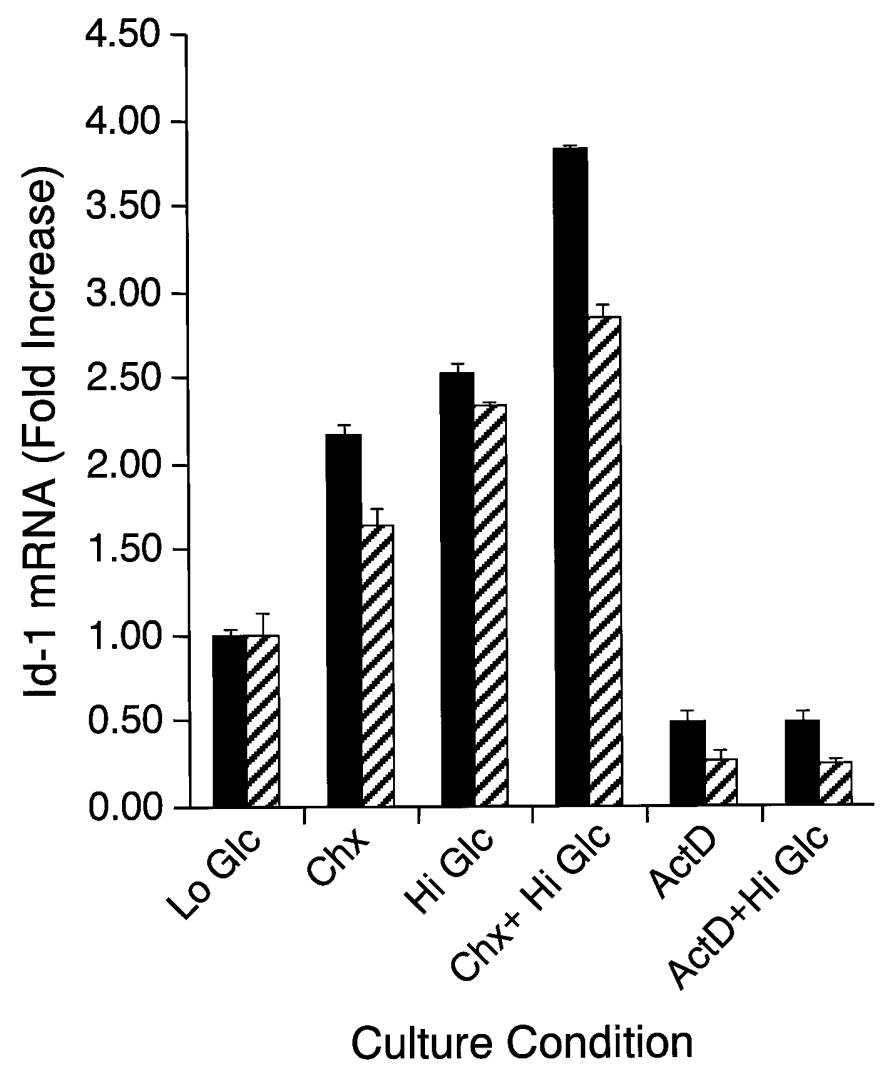

Fig. 6. $I d-1$ acts as an early response gene in beta cells. MIN6 cells were treated as in Fig. 3. Following $24 \mathrm{~h}$ in media containing $2.5 \mathrm{mmol} / \mathrm{l}$ glucose (Lo Glc), cells were harvested for northern blot analysis. As indicated, some cells received $25 \mathrm{mmol} / \mathrm{l}$ glucose (Hi Glc) for the final $30 \mathrm{~min}$. Cycloheximide $(\mathrm{Chx} ; 1 \mu \mathrm{g} / \mathrm{ml})$ or Actinomycin D (Act D; $10 \mu \mathrm{g} / \mathrm{ml})$ was added $60 \mathrm{~min}$ before cells were harvested. "Fold Increase" is relative to Id-1 mRNA concentrations in cells pre-incubated for $24 \mathrm{~h}$ in $2.5 \mathrm{mmol} / \mathrm{l}$ glucose. Solid and hatched bars represent results from 2 independent experiments $(n=5)$. Values are \pm SEM

crease in Id-1 mRNA concentrations in MIN6 cells. Of note, cycloheximide did not prevent the glucoseinduced increase in Id-1 mRNA indicating that de novo protein synthesis is not required for induction of Id-1 mRNA expression. The effects of glucose plus cycloheximide seem to be additive rather than synergistic. Treatment with Actinomycin D resulted in a two to fourfold decrease in Id-1 mRNA concentrations. Addition of $25 \mathrm{mmol} / \mathrm{l}$ glucose did not perturb this decrease indicating that high glucose does not drastically alter Id-1 mRNA stability and de novo RNA synthesis is required for the rapid accumulation of Id-1 mRNA. Therefore, glucose induction of Id expression seems to be an early growth response for beta-cells.

Transient transfection studies with luciferase reporter constructs were used to further address the effect of glucose on Id-1 gene expression. Long-term or short-term exposure of cells to high glucose resulted in a two to threefold increase in luciferase activity in cells transfected with 6.3/Luc (Fig. 7). Similar results 

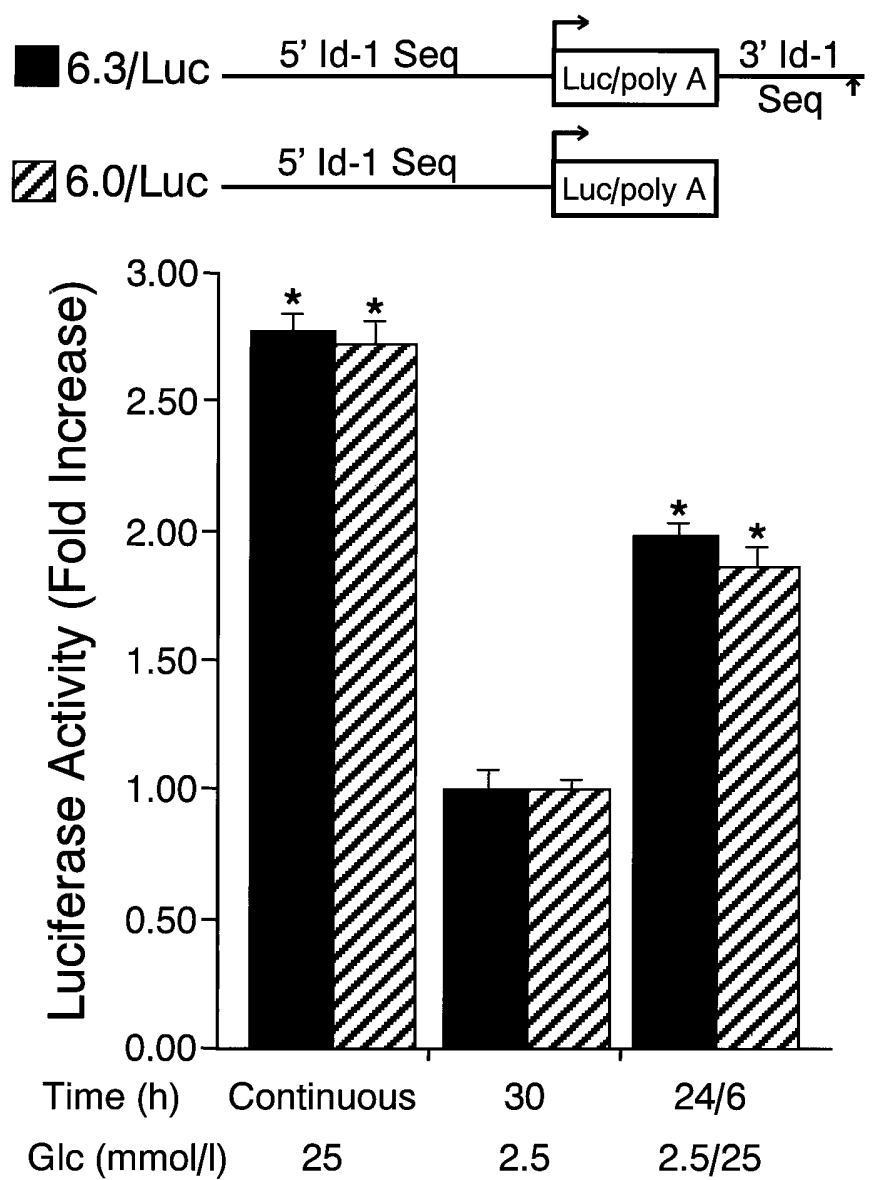

Fig.7. Glucose regulates Id-1 promoter-reporter construct activity. MIN6 cells were transfected with either the 6.3/Luc or 6.0/Luc reporter construct in standard media. The arrow indicates the location of the pro B-lymphocyte enhancer in the 3'flanking region of the $I d-1$ gene. $48 \mathrm{~h}$ after transfection, cells were switched to media containing $2.5 \mathrm{mmol} / \mathrm{l}$ glucose (Lo Glc) and $2.5 \%$ serum, cultured for an additional $24 \mathrm{~h}$, and then harvested for measurement of luciferase activity. As indicated, some cells received $25 \mathrm{mmol} / \mathrm{l}$ glucose (Hi Glc) for the final $6 \mathrm{~h}$. Control cells were maintained in $25 \mathrm{mmol} / \mathrm{l}$ glucose at all times ("Continuous"). All values \pm SEM are normalized to luciferase activity from control cells. The asterisk represents a $p$ value less than 0.003 relative to cells cultured for $30 \mathrm{~h}$ in $2.5 \mathrm{mmol} / \mathrm{l}$ glucose. Similar results have been obtained in more than 6 independent experiments

were obtained with cells transfected with the 6.0/Luc plasmid. Therefore, beta-cell Id-1 mRNA expression is regulated (at least in part) by changes in $I d-1$ gene transcription and 3'-flanking sequences are not required for this response.

Our results suggest that $I d-1$ acts as an earlygrowth-response gene during glucose signalling in beta cells. In both MIN6 and $\beta$ TC6-F7 cells, TAg expression is driven using the insulin promoter. This raised the possibility that increased Id-1 and Id3 mRNA concentrations resulted from a concomitant TAg-associated, mitogenic signal rather than from increased insulin secretion and production. To address
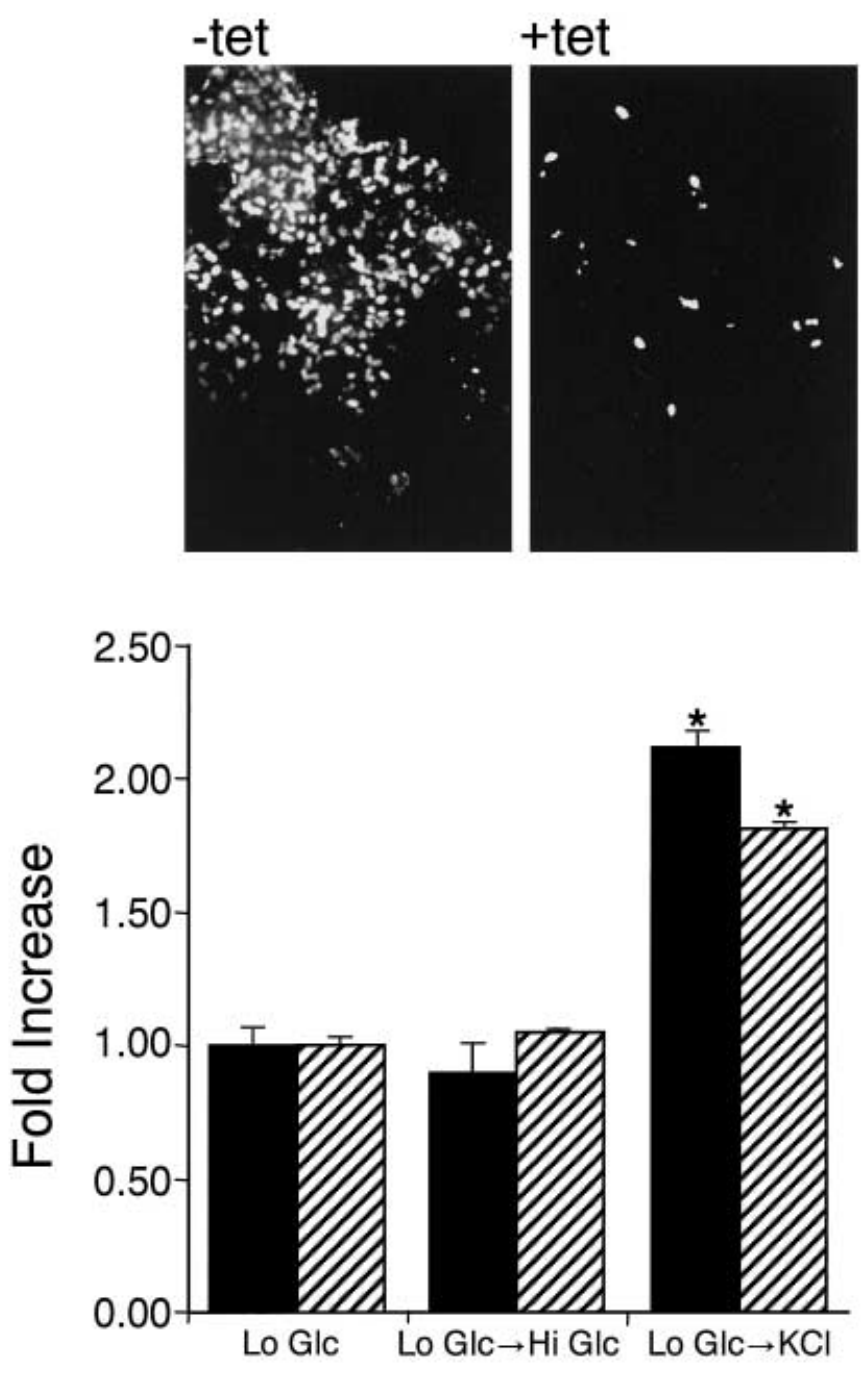

\section{Culture Condition}

Fig.8(A, B). Regulation of $I d-1$ expression is independent of TAg expression and cellular proliferation. (A) $\beta$ TC-tet cells cultured in the presence $(+)$ or absence $(-)$ of $1 \mu \mathrm{mol} / 1$ tetracycline (tet) were labelled with BrdU and then analysed by indirect immunofluorescence for BrdU-labelled DNA (white nuclei). An identical staining pattern was observed after staining with rabbit anti-TAg primary antibodies (not shown). Similar results were obtained in 2 independent experiments. (B) $\beta$ TC-tet cells were cultured for $24 \mathrm{~h}$ in media containing $2.5 \mathrm{mmol} / \mathrm{l}$ glucose and $1 \mu \mathrm{mole} / 1$ tetracycline (Lo Glc). Some cells received $25 \mathrm{mmol} / \mathrm{l}$ glucose (Lo Glc $\rightarrow \mathrm{Hi}$ Glc) or $30 \mathrm{mmol} / \mathrm{l} \mathrm{KCl}(\mathrm{Lo} \mathrm{Glc} \rightarrow \mathrm{KCl}$ ) for the final 30 (for RNA) or 90 (for secretion) min. Values are \pm SEM. The asterisk represents a $p$ value of less than 0.01. Experiments measuring Id-1 mRNA concentrations and insulin secretion have been done 2 and 3 times, respectively, with similar results. Id-1 mRNA; $\mathbb{Z}$, insulin secretion

this issue, we examined $I d-1$ expression in the $\beta \mathrm{TC}$ tet cell line. These cells were established from an insulinoma in which TAg, and thus, proliferation can be extinguished by culturing these cells in media containing tetracycline. More than $90 \%$ of the cells cultured for 7 days in the presence of $1 \mu \mathrm{mol} / 1$ tetracy- 
cline no longer expressed detectable levels of TAg (not shown). More importantly, most tetracyclinetreated cells ceased to proliferate because incorporation of BrdU into newly synthesized DNA was no longer detectable (Fig. 8A). Treatment of the $\beta$ TCtet cells with $30 \mathrm{mmol} / \mathrm{l} \mathrm{KCl}$ resulted in twofold increases in insulin secretion and Id-1 mRNA concentrations (Fig. 8B). Therefore, these cells responded to $\mathrm{KCl}$ induced depolarization in the same fashion as MIN6 and $\beta$ TC6-F7 cells. Adding $25 \mathrm{mmol} / 1$ glucose to cells pre-incubated for $24 \mathrm{~h}$ in low glucose did not induce either insulin secretion or $I d-1$ expression in $\beta$ TC-tet cells. This result also confirms that increased $I d-1$ expression requires intact beta-cell glucose signalling.

\section{Discussion}

Because of their ability to sequester E-proteins, Ids have been thought to act as inhibitors of cell differentiation. In fact, forced expression of Id-1 can reduce expression of an insulin promoter-luciferase reporter construct in HIT insulinoma cells [22]. The physiological relevance of this result has never been addressed because it has not been reported if Ids are expressed in these cells or if glucose regulates $I d$ gene expression in beta cells. In this study, we have shown that Id genes are expressed in pancreatic islets and betacell lines and that glucose and other insulin secretagogues regulate Id mRNA expression. Transfection experiments using $I d-1$ promoter-luciferase reporter constructs indicate that this regulation occurs by altering the rate of $I d-1$ gene transcription. As bHLH transcription factors are critical for activity of the insulin promoter, one might have predicted that glucose and other insulin secretagogues would have inhibited expression of $I d$ genes. Glucose and insulin secretagogues, however, actually increased Id-1 and Id-3 mRNA concentrations in beta cells. This suggests that Ids promote, rather than inhibit, insulin gene transcription. Because glucose induces a biphasic change in Id-1 and Id-3 mRNA and protein concentrations, these Ids could regulate rapid as well as long-term responses to changes in glucose concentrations. It is also possible that Ids regulate a bHLH-independent aspect(s) of the beta-cell phenotype. Because glucose had little effect on Id expression in HepG2, BC3H1, and CaCo-2 cells, the Id response is fairly specific for beta cells. Because a host of insulin secretagogues in addition to glucose induces $I d$ gene expression in MIN6 and this response was not prevented by cycloheximide, Ids might be important for integrating diverse signalling pathways in beta cells immediately after stimulation by secretagogues.

The concept that Ids actually promote the betacell phenotype has precedence. The concentration of Id-1 mRNA in islets is similar to that in the jejunum
(Fig.1). Immunohistochemical localization of Id proteins in the small intestine showed that highest concentrations of Ids are encountered in non-proliferating, fully differentiated, villus-associated epithelial cells. Consistent with this observation, forced expression of Id-1 in the intestinal epithelium in vivo does not inhibit cell differentiation [56]. As bHLH proteins are required for secretin and cholecystokinin production by entero-endocrine cells $[12,65]$ and insulin gene transcription by beta-cells $[12,65]$, Id proteins are not simply sequestering E-proteins. Relatively high concentrations of Id- 1 were observed in lung and placenta. These observations further support the notion that Id- 1 is not a general inhibitor of cell differentiation.

Our results suggest that physiological concentrations of Ids do not inhibit insulin gene transcription. One model to explain this possibility is that Ids can sequester both positive and negative acting bHLH molecules. By titrating the concentrations of these proteins, Ids can act as either activators or inhibitors of bHLH function. For example, insulin secretagogues could induce relatively low concentrations of Id expression which could promote insulin gene transcription by sequestering BETA3 [66], HES-1 [67], or other unidentified inhibitory bHLH proteins, or both. Any further increase in Id concentrations might result in sequestration of positive acting bHLH proteins such as BETA2 or E-proteins. This, in turn, would inhibit insulin gene transcription. This model can explain why forced expression of non-physiological concentrations of Id-1 in insulinoma cells inhibited insulin promoter activity $[22,68]$.

Our results indicate that Id proteins could play novel and unexpected roles in promoting the beta-cell phenotype. Individual Id proteins exhibit unique affinities for different bHLH proteins [17] and for different non-bHLH proteins. It is the sum of these interactions that will determine a biological effect. Typically, experiments examining protein function are carried out by expressing high, non-physiological concentrations of the protein of interest and this could mask the physiological role for the protein in question. We are therefore currently developing systems in which expression of Id proteins can be manipulated within physiological limits. Such systems should be useful for determining the physiological functions for Id proteins in islet beta cells.

Acknowledgements. This work was supported in part by National Institutes of Health Grant DK16746-28. Primary human islets, oligonucleotides, and insulin radioimmunoassays were provided by Washington University's Diabetes Research and Training Center through National Institutes of Health Grant 5P60DK2 057923. B. M. Wice is supported by a Career Development Award from the American Diabetes Association. The authors would like to thank Michael Shornick for his expert technical assistance. 


\section{References}

1. Rhodes C (1996) Processing of the Insulin Molecule. In: LeRoith D, Taylor SI, Olefsky JM (eds) Diabetes Mellitus: A fundamental and clinical text. Lippencott-Raven, Philadelphia, pp 27-41

2. Docherty K, Clark AR (1994) Nutrient regulation of insulin gene expression. FASEB Journal $8: 20-27$

3. Sander M, German MS (1997) The $\beta$ cell transcription factors and development of the pancreas. J Mol Med 75: 327-340

4. Kennedy GC, German MS (1996) Insulin gene regulation. In: LeRoith D, Taylor SI, Olefsky JM (eds) Diabetes Mellitus: A fundamental and clinical text. Lippincott-Raven, Philadelphia, pp 20-26

5. Karlsson O, Edlund T, Moss JB, Rutter WJ, Walker MD (1987) A mutational analysis of the insulin gene transcription control region: expression in beta-cells is dependent on two related sequences within the enhancer. Proc Nat Acad Sci, USA 84: 8819-8823

6. Odagiri H, Wang J, German MS (1996) Function of the Human Insulin Promoter in Primary Cultured Islet Cells. J Biol Chem 271: 1909-1915

7. Dias P, Dilling M, Houghton P (1994) The molecular basis of skelatal muscle differentiation. Semin Diagn Pathol 11: 3-14

8. Kadesch T (1993) Consequences of heteromeric interactions among helix-loop-helix proteins. Cell Growth Differ $4: 49-55$

9. Jan YN, Jan LY (1993) HLH proteins, fly neurogenesis, and vertabrate myogenesis. Cell 75: 827-830

10. Olson EN, Klein WH (1994) bHLH factors in muscle development: deadlines and commitments, what to leave in and what to leave out. Genes Dev 8: 1-8, Abstract

11. Naya FJ, Stellrecht CMM, Tsai M-J (1995) Tissue-specific regulation of the insulin gene by a novel basic helix-loophelix transcription factor. Genes Dev 9: 1009-1019

12. Naya FJ, Huang H-P, Qiu Y et al. (1997) Diabetes, defective pancreatic morphogenesis, and abnormal enteroendocrine differentiation in BETA2/NeuroD-deficient mice. Genes Devel 11: 2323-2334

13. Malecki MT, Jhala US, Antonellis A et al. (1999) Mutations in NEUROD1 are associated with the development of Type II diabetes mellitus. Nat Genet 23: 323-328

14. Sharma A, Henderson E, Gamer L, Zhuang Y, Stein R (1997) Analysis of the role of E2A-encoded proteins in insulin gene transcription. Mol Endocrinol 11: 1608-1617, Abstract

15. Itkin-Ansari P, Bain G, Beattie GM, Murre C, Hayek A, Levine F (1996) E2A gene products are not required for insulin gene expression. Endocrinology 137: 3540-3543

16. Norton JD, Deed RW, Craggs G, Sablitzky F (1998) Id helix-loop-helix proteins in cell growth and differentiation. Trends Cell Biol 8: 58-65

17. Langlands K, Yin X, Anand G, Prochownik EV (1997) Differential interactions of Id proteins with basic-helix-loophelix transcription factors. J Biol Chem 272: 19785-19793

18. Cross JC, Flannery ML, Blanar MA et al. (1995) Hxt encodes a basic helix-loop-helix trancription factor that regulates trophoblast cell development. Development 121: 2513-2523

19. Jen Y, Weintraub H, Benezra R (1992) Overexpression of Id protein inhibits the muscle differentiation program: in vivo association of Id with E2A proteins. Genes Dev 6: 1466-1479

20. Sun X-H (1994) Constitutive expression of the Id1 gene impairs mouse B cell development. Cell 79 : 893-900
21. Therrien M, Drouin J (1993) Cell-specific helix-loop-helix factor required for pituitary expression of the pro-opiomelanocortin gene. Mol Cell Biol 13: 2342-2353

22. Cordle SR, Henderson E, Masuoka H, Weil PA, Stein R (1991) Pancreatic $\beta$-cell-type-specific transcription of the insulin gene is mediated by basic helix-loop-helix DNAbinding proteins. Mol Cell Biol 11: 1734-1738

23. Murray SS, Glackin CA, Winters KA, Gazit D, Kahn AJ, Murray, EJ (1992) Expression of helix-loop-helix regulatory genes during differentiation of mouse osteoblastic cells. J Bone Miner Res 7: 1131-1138

24. Kreider BL, Benezra R, Rovera G, Kadesch T (1992) Inhibition of myeloid differentiation by the helix-loop-helix protein Id. Science 255: 1700-1702

25. Desprez P-Y, Hara E, Bissell MJ, Campisi J (1995) Suppression of mammary epithelial cell differentiation by the helix-loop-helix protein Id-1. Mol Cell Biol 15: 3398-3404

26. Shoji W, Yamamoto T, Obinata M (1994) The helix-loophelix protein Id inhibits differentiation of murine erythroleukemia cells. J Biol Chem 269: 5078-5084

27. Yates PR, Atherton GT, Deed RW, Norton JD, Sharrocks AD (1999) Id helix-loop-helix proteins inhibit nucleoprotein complex formation by the TCF ETS-domain transcription factors. EMBO J 18: 968-976

28. Lasorella A, Iavarone A, Israel MA (1996) Id2 specifically alters regulation of the cell cycle by tumor suppressor proteins. Mol Cell Biol 16: 2570-2578

29. Hara E, Yamaguchi T, Nojima H, Ide T, Campisi J, Okayama H, Oda K (1994) Id-related genes encoding helixloop-helix proteins are required for G1 progression and are repressed in senescent human fibroblasts. J Biol Chem 269: 2139-2145

30. Peverali FA, Ramqvist T, Saffrich R, Pepperkok R, Barone MV, Philipson L (1994) Regulation of G1 progression by E2A and Id helix-loop-helix proteins. EMBO J 13: 4291-4301

31. Iavorone A, Garg P, Lasorella A, Hsu J, Israel MA (1994) The helix-loop-helix protein Id-2 enhances cell proliferation and binds to the retinoblastoma protein. Genes Dev 8: $1270-1284$

32. Norton JD, Atherton GT (1998) Coupling of cell growth control and apoptosis functions of Id proteins. Mol Cell Biol 18: 2371-2381

33. Florio M, Hernandez M-C, Yang H, Shu H-K, Cleveland JL, Israel MA (1998) Id2 promotes apoptosis by a novel mechanism independent of dimerization to basic helixloop-helix factors. Mol Cell Biol 18: 5435-5444

34. Kim D, Peng X-C, Sun X-H (1999) Massive apoptosis of thymocytes in T-cell-deficient Id1 transgenic mice. Mol Cell Biol 19: 8240-8253

35. Andres-Barquin PJ, Hernandez M-C, Israel MA (1999) Id4 expression induces apoptosis in astrocytic cultures and is down-regulated by activation of the cAMP-dependent signal transduction pathway. Exp Cell Res 247: 347-355

36. Anand G, Yin X, Shahidi AK, Grove L, Prochownik EV (1997) Novel regulation of the helix-loop-helix protein Id1 by $\mathrm{S} 5 \mathrm{a}$, a subunit of the $26 \mathrm{~S}$ proteasome. J Biol Chem 272: 19140-19151

37. Wilkinson KD (1995) Roles of ubiquitinylation in proteolysis and cellular regulation. Ann Rev Nutr 15: 161-189

38. Hershko A, Ciechanover A (1998) The ubiquitin system. Ann Rev Biochem 67: 425-479

39. Knaack D, Fiore DM, Surana M, Leiser M, Laurance M, Fusco-DeMane D, Hegre OD, Fleischer N, Efrat S (1994) Clonal insulinoma cell line that stably maintains correct glucose responsiveness. Diabetes 43: 1413-1417 
40. Efrat S, Fusco-DeMane D, Lemberg H, Al Emran O, Wang $\mathrm{X}$ (1995) Conditional transformation of a pancreatic $\beta$-cell line derived from transgenic mice expressing a tetracycline-regulated oncogene. Proc Natl Acad Sci USA 92: 3576-3580

41. Miyazaki J-I, Araki K, Yamato E et al. (1990) Establishment of a pancreatic $\beta$ cell line that retains glucose-inducible insulin secretion: special reference to expression of glucose transporter isoforms. Endocrinology 127: 126-132

42. Mayor P, Maianu L, Garvey T (1992) Glucose and insulin chronically regulate insulin action via different mechanisms in BC3H1 myocytes. Diabetes 41: 274-285

43. Matosin-Matekalo M, Mesonero JE, Delezay O, Poiree JC, Ilundain AA, Brot-Laroche E (1998) Thyroid hormone regulation of the $\mathrm{Na}+$ /glucose cotransporter SGLT1 in Caco- 2 cells. Biochem J 334: 633-640

44. Matosin-Matekalo M, Mesonero JE, Laroche TJ, LaCasa M, Brot-Laroche E (1999) Glucose and thyroid hormone co-regulate the expression of the intestinal fructose transporter GLUT5. Biochem J 339: 233-239

45. Rodolosse A, Chantret I, LaCasa M et al. (1996) A limited upstream region of the human sucrase-isomaltase gene confers glucose-regulated expression on a heterologous gene. Biochem J 315: 301-306

46. Rodolosse A, Carriere V, Chantret I, LaCasa M, Zweibaum A, Rousset M (1997) Glucose-dependent transcriptional regulation of the human sucrase-isomaltase (SI) gene. Biochimie 79: 119-123

47. Mesonero J, Matosin M, Cambier D, Rodriguez-Yoldi M-J, Brot-Laroche E (1995) Sugar-dependent epxression of the fructose transporter GLUT5 in Caco-2 cells. Biochem J 312: 757-762

48. Bernet-Camard M-F, Duigou F, Kerneis S, Coconnier MH, Servin AL (1997) Glucose up-regulates expression of the differentiation-associated brush border binding site for enterotoxigenic Escherichia coli colonization factor antigen $I$ in cultured human enterocyte-like cells. Infection and Immunity 65: 1299-1306

49. Barbosa-Tessman IP, Pineda VL, Nick HS, Schuster SM, Kilberg MS (1999) Transcriptional regulation of the human asparagine synthetase gene by carbohydrate availability. Biochem J 339: 151-158

50. Tan J, Yang H-S, Patel MS (1998) Regulation of mammalian pyruvate dehydrogenase $\alpha$ subunit gene expression by glucose in HepG2 cells. Biochem J 336: 49-56

51. Semenkovich CF, Coleman T, Goforth R (1993) Physiologic concentrations of glucose regulate fatty acid synthase activity in HepG2 cells by mediating fatty acid synthase mRNA stability. J Biol Chem 268: 6961-6970

52. Wice BM, Milbrandt J, Glaser L (1987) Control of muscle differentiation in $\mathrm{BC} 3 \mathrm{H} 1$ cells by fibroblast growth factor and vanadate. J Biol Chem 262: 1810-1817

53. Wice BM, Trugnan G, Pinto M, et al. (1985) The intracellular accumulation of UDP-N-acetylhexosamines is concomitant with the inablility of human colon cancer cells to differentiate. J Biol Chem 260: 139-146

54. Olack BJ, Swanson CJ, Howard TK, Mohanakumar T (1999) Improved method for the isolation and purification of human islets of Langerhans using Liberase (TM) enzyme blend. Hum Immunol 60: 1303 -1309

55. Sagerstrom CG, Sive HL (1996) RNA blot analysis. In: Krieg PA (ed) A Laboratory Guide to RNA: Isolation, Analysis, and Synthesis. Wiley-Liss, Inc., New York, pp 83-103

56. Wice BM, Gordon JI (1998) Forced expression of Id-1 in the adult mouse small intestinal epithelium is associated with development of adenomas. J Biol Chem 273: 25310-25319

57. Riechmann V, van Cruchten I, Sablitzky F (1994) The expression pattern of Id4, a novel dominant negative helixloop-helix protein, is distinct from Id1, Id2, and Id3. Nucleic Acids Res 22: 749-755

58. Boudreaux JM, Towler DA (1996) Synergistic induction of osteocalcin gene expression. J Biol Chem 271: 7508-7515

59. Hernandez M-C, Andres-Barquin PJ, Israel MA (1996) Molecular cloning of the cDNA encoding a helix-loop-helix protein, mouse ID1B: tissue -specific expression of ID1A and ID1B genes. Biochim Biophys Acta 1308: 28-30

60. Wice BM, Gordon JI (1995) A tetraspan membrane glycoprotein produced in the human intestinal epithelium and liver that can regulate cell density-dependent proliferation. J Biol Chem 270: 21907-21918

61. Sandler S, Eizirik DL (1994) Culture of human pancreatic islet cells. In:Jones, G. E. (eds) Methods in Molecular Medicine: Human Cell Culture Protocols. Humana Press, Inc., Totowa, New Jersey, pp 391-407

62. Saisanit S, Sun X-H (1995) A novel enhancer, the pro-B enhancer, regulates Id1 gene expression in progenitor B cells. Mol Cell Biol 15: 1513-1521

63. Tournay O, Benezra R (1996) Transcription of the dominant-negative helix-loop-helix protein Id1 is regulated by a protein complex containing the immediate-early response gene Egr-1. Mol Cell Biol 16: 2418-2430

64. Ezura Y, Tournay O, Nifuji A, Noda M (1997) Identification of a novel suppressive vitamin $\mathrm{D}$ response sequence in the 5'-flanking region of the murine Id1 gene. J Biol Chem 272: 29865-29872

65. Mutoh H, Fung BP, Naya FJ, Tsai M-J, Nishitani J, Leiter AB (1997) The basic helix-loop-helix transcription factor BETA2/NeuroD is expressed in mammalian enteroendocrine cells and activates secretin gene expression. Proc Natl Acad Sci USA 94: 3560 -3564

66. Peyton M, Stellrecht CMM, Naya FJ, Huang H-P, Samora PJ, Tsai M-J (1996) BETA3, a novel helix-loop-helix protein, can act as a negative regulator of BETA2 and MyoDresponsive genes. Mol Cell Biol 16: 626-633

67. Jensen J, Pedersen EE, Galante P (2000) Control of endodermal endocrine development by Hes-1. Nat Genet 24: $36-44$

68. Robinson GL, Cordle SR, Henderson E, Weil PA, Teitelman G, Stein R (1994) Isolation and characterization of a novel transcription factor that binds to and activates insulin control element-mediated expression. Mol Cell Biol 14: 6704-6714 